Effect of $\mathrm{Ni}$ and $\mathrm{Zr}$ on the microstructural evaluation of Ti-based alloys during ball-milling

\author{
Maria Sveda $^{\mathrm{a}}$, Anna Sycheva ${ }^{\mathrm{a}}$, Tamas Miko ${ }^{\mathrm{a}}$, Ferenc Kristaly ${ }^{\mathrm{b}}$, Adam Racz $^{\mathrm{c}}$, Tibor Ferenczi ${ }^{\mathrm{d}}$, \\ Dora Janovszky ${ }^{\mathrm{a}}$ \\ ${ }^{a}$ MTA-ME Material Science Research Group, Miskolc-Egyetemvaros, Hungary \\ ${ }^{b}$ Institute of Mineralogy and Geology, University of Miskolc, Hungary \\ ${ }^{\mathrm{c}}$ Institute of Raw Material Preparation and Environmental Processing, University of Miskolc, \\ Hungary
}

d Institute of Metallurgical and Foundry Engineering, University of Miskolc, Hungary

In this paper, the effect of ball milling on Ti-based amorphous powders with nominal compositions of $\mathrm{Ti}_{48} \mathrm{Cu}_{39.5} \mathrm{Ni}_{10} \mathrm{Co}_{2.5}$ and $\mathrm{Ti}_{48} \mathrm{Cu}_{39.5} \mathrm{Zr}_{10} \mathrm{Co}_{2.5}$ (at. \%) was studied. For this purpose, $\mathrm{Ni}$ and $\mathrm{Zr}$ containing crystalline master alloys were ball-milled for 20 hours in total. According to XRD analysis, the maximal amorphous fraction has been achieved in the case of $\mathrm{Ni}$ containing powder after 5 hours of milling. The nanocrystalline phase of $\mathrm{CuTi}_{3}(\mathrm{Ni})$ having a grain size of $0.17-0.29 \mathrm{~nm}$ formed in the early stages of the milling process and remained stable until the end of milling. The amorphous-nanocrystalline transition of this phase is a reversible process. The amorphization process of $\mathrm{Ti}_{48} \mathrm{Cu}_{39.5} \mathrm{Zr}_{10} \mathrm{Co}_{2.5}$ is not so rapid than that in the Ni containing alloy system. This confirms that kinetic energy of the milling process is insufficient for destabilization of the $\mathrm{Cu}_{2} \mathrm{ZrTi}_{2}$ nanocrystalline $(0.15-0.26 \mathrm{~nm})$ phase. The microhardness of $\mathrm{Ti}_{48} \mathrm{Cu}_{39.5} \mathrm{Ni}_{10} \mathrm{Co}_{2.5}$ and $\mathrm{Ti}_{48} \mathrm{Cu}_{39.5} \mathrm{Zr}_{10} \mathrm{Co}_{2.5}$ particles was found to be $\mathrm{HV}_{0.01}$ $519 \pm 40$ and $630 \pm 55$, respectively. For both compositions amorphous-nanocrystalline composites have been successfully obtained.

Keywords: metallic glasses, amorphous-nanocrystalline composites, Ti-based amorphous alloys, ball-milling, powder metallurgy, microstructure, mechanical properties

\title{
Introduction
}

Since the discovery of the first "Metallic Glass" of composition $\mathrm{Au}_{75} \mathrm{Si}_{25}$ in 1960 it has become a very interesting topic for metallurgists and material scientists to study the rapidly solidified alloys [1]. Recently, much attention has been paid to develop Ti-based bulk amorphous alloys due to their high specific strength and low cost [2-5]. There is no widespread use of Ti-based amorphous materials yet, although their small density and large hardness is a favorable combination of properties. A number of Ti-based bulk glass-forming alloys, such as Ti-Cu-Ni-(Sn or Sb), Ti-Cu-Ni-Si-B, Ti-Zr-Ni-Cu-Sn and Ti-Cu-Ni-Zr-Al-Si-B, (Ti, Zr)-(Cu, $\mathrm{Ni}$ ) have been synthesized by the copper casting method [6-8]. Amorphous alloys with critical thickness above $5 \mathrm{~mm}$ usually contain toxic elements such as beryllium. The predicted composition range of formation of rapidly-quenched and bulk fully amorphous alloys is very narrow [9]; this is the explanation for the existence of several Ti-based composites and not fully amorphous alloy.

Powder metallurgy is an alternative way that allows producing centimeter-sized amorphous pieces from amorphous powders. The first step of this procedure is the preparation of amorphous powder from a crystalline material by high-energy milling [10]. 
The Ti-Cu-Zr-Ni system is a special one, since it has three bulk metallic glass (BMG) composition regions on the Ti-, $\mathrm{Zr}$ - and $\mathrm{Cu}$-rich side [11-14]. To design new Ti-Cu-based BMG composites an early transition metal $\mathrm{Ni}$, a late transition metal $\mathrm{Zr}$ or a third transition metal $\mathrm{Co}$ can be added to the basic alloys to improve the glass-forming ability (GFA) of the glass-matrix. The atomic radii are in this case, $\mathrm{Ni}=0.124 \mathrm{~nm}, \mathrm{Cu}=0.128 \mathrm{~nm}, \mathrm{Ti}=0.147 \mathrm{~nm}$ and $\mathrm{Zr}=0.16$ $\mathrm{nm}$. Considering the alloying element such as Co $(0.125 \mathrm{~nm})$ it has the second smallest atomic radius. Therefore, in principle, with combination of these elements, efficiently packed local structure can be produced, which is related to high viscosity of liquids. There are only few reports, which deal mainly with the Ni-Co and Zr-Co combined addition influence, but still they are not systematically studied. Inoue's rules can help select alloying elements to stabilize the super-cooled liquid and create amorphous alloys easily. Using Co as alloying element for $\mathrm{CuZrTi}$, the packed local structure can be enhanced in the aforementioned system [15]. The addition of Co to CuZrTi and CuNiTi alloy is expected to cause distortion of its local atomic order due to the large atomic size mismatch.

The bonding forces between the metallic atoms influence the thermal stability of amorphous alloys. The heat of mixing of $\mathrm{Cu}, \mathrm{Ni}, \mathrm{Co}$ and $\mathrm{Zr}$ with $\mathrm{Ti}$ are $-9,-35,-28$ and 0 $(\mathrm{kJ} / \mathrm{mol})$, respectively [12]. In the $\mathrm{Cu}-\mathrm{Zr}-\mathrm{Ti}$ and $\mathrm{Cu}-\mathrm{Ni}-\mathrm{Ti}$ system, the heat of mixing between the elements is negative, which means that the bonding forces between the atoms are strong. It is worth adding such an element to the alloy that has positive heat of mixing since it enhances disordering. It is positive in the case of $\mathrm{Ni}-\mathrm{Cu}$ and $\mathrm{Cu}-\mathrm{Co}[11,12]$. Despite numerous reports available in scientific literature, the influence of $\mathrm{Zr}$-Co and Ni-Co addition on the glass formation and microscopic properties was neither studied nor precisely understood. This paper reports systematic characterization of the microstructure evolution of $\mathrm{Ti}_{48} \mathrm{Cu}_{39.5} \mathrm{Ni}_{10} \mathrm{Co}_{2.5}$ and $\mathrm{Ti}_{48} \mathrm{Cu}_{39.5} \mathrm{Zr}_{10} \mathrm{Co}_{2.5}$ arc-melted alloys in the course of ball-milling.

\section{Experimental processing}

Master alloy ingots with the compositions $\mathrm{Ti}_{48} \mathrm{Cu}_{39.5} \mathrm{Ni}_{10} \mathrm{Co}_{2.5}$ and $\mathrm{Ti}_{48} \mathrm{Cu}_{39.5} \mathrm{Zr}_{10} \mathrm{Co}_{2.5}$ were prepared by arc melting of pure metal mixtures (min. 99.9 wt. \%) with a Ti-getter under purified argon atmosphere. The master alloys were grinded and fractioned to a particle size below 300 $\mu \mathrm{m}$ for ball milling. Amorphous/nanostructured powders were obtained in a Pulverisette 5 highenergy ball-mill in argon atmosphere using a stainless steel vial and balls with a diameter of 7, 10 , and $20 \mathrm{~mm}$. The ball-to-powders ratio was 60:1 and 80:1 and milling speed was $200 \mathrm{rpm}$. The micrographs of master alloys and powders were acquired by a Hitachi S-4800 scanning electron microscope (SEM) equipped with BRUKER AXS type energy-dispersive X-ray spectrometer (EDS). Backscattered electron micrographs were recorded in order to get information about the microstructure of the samples. The particle size distribution of the ground material was determined by a Horiba LA-950 V2 type laser diffraction particle size analyzer in distilled water. During the measurement process 1 minute ultrasonic treatment and $1 \mathrm{ml}$ of 50 $\mathrm{g} / \mathrm{l}$ sodium pyrophosphate dispersant were applied to achieve the appropriate dispersity state. Thermal analysis was performed in a Netzsch $204 \mathrm{DSC}$ at a heating rate of $0.66 \mathrm{~K} / \mathrm{s}$ under a flow of purified argon. The samples were examined by Bruker D8 Advance diffractometer (XRD) using $\mathrm{Cu} \mathrm{K \alpha}$ radiation $(40 \mathrm{kV}, 40 \mathrm{~mA})$, in parallel beam geometry obtained with Göbel mirror, equipped with Vantec-1 position sensitive detector $\left(1^{\circ}\right.$ window opening), measured in the $2-100^{\circ}(2 \theta)$ angular range, with $0.007^{\circ}(2 \theta) / 29 \mathrm{sec}$ speed. The specimen is rotated in sample plane during the measurement, to obtain data from the whole surface and to reduce in- 
plane preferred orientation effects. The crystalline fraction was determined by XRD analysis using peak area determination in TOPAS4 (amorphous hump method). Quantitative results were obtained by combined use of Rietveld refinement and peak area calculation. Hardness measurements were performed by Wolpert UH 930 equipment applying a load of $30 \mathrm{~kg}$ for 15 $\mathrm{s}$ for all composites. Microhardness measurements were performed by Instron Tukon 2100B equipment, applying a load of $10 \mathrm{~g}$ for $15 \mathrm{~s}$ for as milled powders.

\section{Results and Discussion}
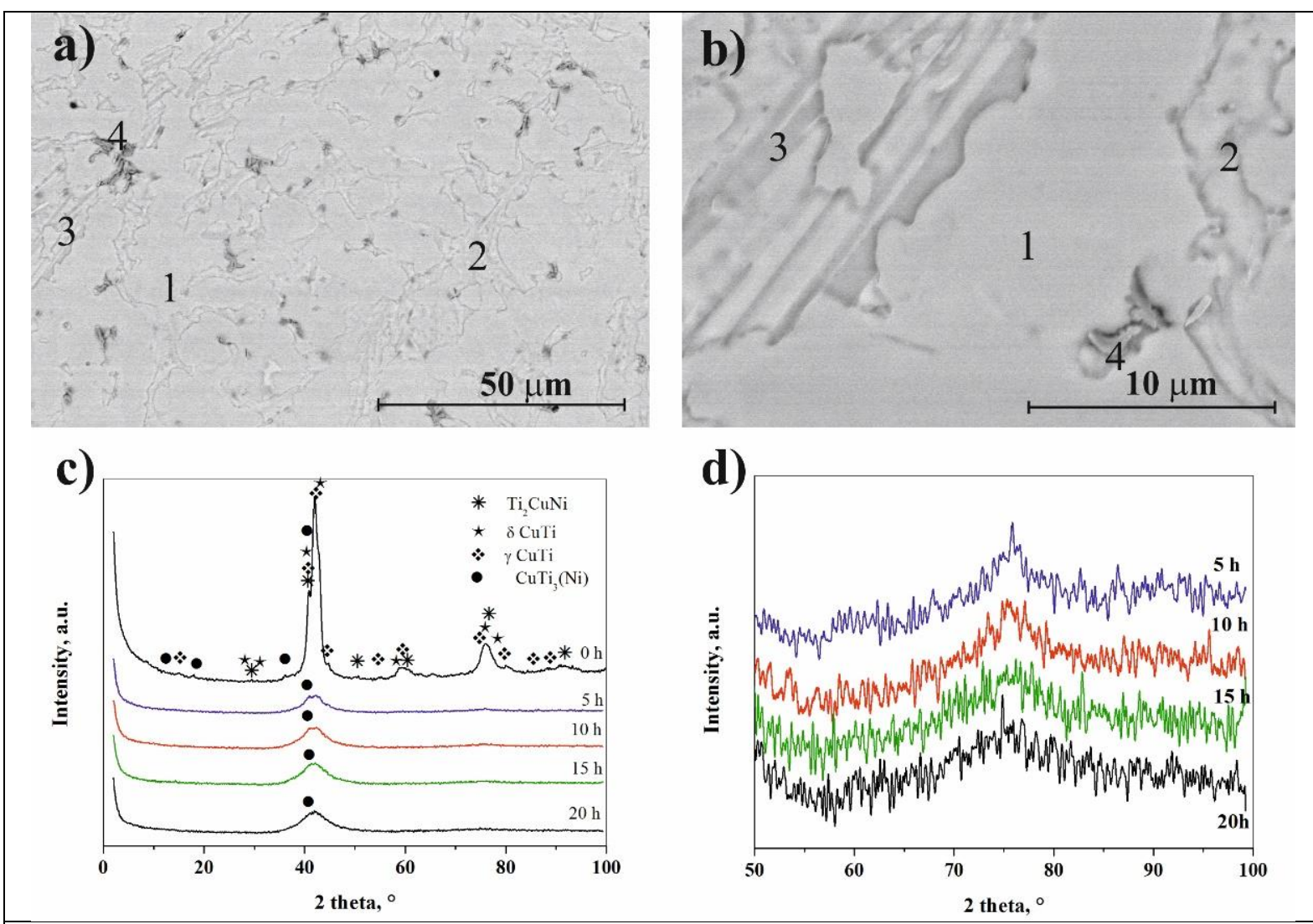

Fig. 1: Backscattered SEM (BSEM) images $(a, b)$ and XRD patterns of powders with different milling time (c, d) of $\mathrm{Ti}_{48} \mathrm{Cu}_{39.5} \mathrm{Ni}_{10} \mathrm{Co}_{2.5}$ alloy.

Four phases were identified based on the XRD patterns and SEM analysis in the master alloy of $\mathrm{Ti}_{48} \mathrm{Cu}_{39.5} \mathrm{Ni}_{10} \mathrm{Co}_{2.5}$ composition. Cubic $\mathrm{Ti}_{2} \mathrm{CuNi}$ dendrites solidified in the matrix (Figs. 1a-b marked as 1), which was reported in [16]. The composition of the $\mathrm{Ti}_{2} \mathrm{CuNi}$ dendrites (Table 1) slightly deviates from the equilibrium composition, $\mathrm{Ni}$ atoms substitute some $\mathrm{Ti}$ atoms, and this phase dissolves most of the Co atoms. Tetragonal $\delta \mathrm{CuTi}$ and $\gamma \mathrm{CuTi}$ were also identified (marked as 2 and 3 in Fig. 1) in the sample. Both phases dissolve some Ni and Co atoms. A small amount of dark gray inclusions (see Fig. 1 marked as 4) was identified by XRD to be tetragonal $\mathrm{CuTi}_{3}$ with needle-like shape $(3-6 \mu \mathrm{m})$ which remains a stable phase based on thermal analysis [17]. The unit cell dimensions of the $\mathrm{CuTi}_{3}$ phase is as follows: $a=0.4158$ $\mathrm{nm}, c=0.3594 \mathrm{~nm}$. However, in our case $a=0.4238 \mathrm{~nm}, c=0.3550 \mathrm{~nm}$, which can be explained by additionally dissolved $\mathrm{Ni}$ atoms. Both $\mathrm{CuTi}$ and $\mathrm{CuTi}_{3}(\mathrm{Ni})$ phases dissolve some Co (Table 1). According to the peak area measurement in the XRD pattern, the volume fractions of the $\mathrm{Ti}_{2} \mathrm{NiCu}$ dendrites, $\delta \mathrm{CuTi}, \gamma \mathrm{CuTi}$ and $\mathrm{CuTi}_{3}(\mathrm{Ni})$ are about $55 \%, 32 \%, 8 \%$ and $5 \%$, respectively in crystallite volume. The average Brinell hardness of the master alloy is $233 \pm 3 \mathrm{HB} 1 / 30$. 
Table 1: Chemical composition and volume fraction of different phases in arc-melted $\mathrm{Ti}_{48} \mathrm{Cu}_{39.5} \mathrm{Ni}_{10} \mathrm{Co}_{2.5}$ master alloy ingot

\begin{tabular}{cccccccc}
\hline Phase & space group & Area & $\begin{array}{c}\mathrm{Ti}, \text { at. } \\
\%\end{array}$ & $\mathrm{Cu}$, at. \% & Ni, at. \% & Co, at. \% & $\begin{array}{c}\text { fraction in } \\
\text { crystalline } \\
\text { volume, } \%\end{array}$ \\
\hline \hline $\mathrm{Ti}_{2} \mathrm{CuNi}$ & $\mathrm{Pm}-3 \mathrm{~m}$ & 1 & $57.6 \pm 1.7$ & $28.5 \pm 2.0$ & $10.6 \pm 0.2$ & $3.3 \pm 0.1$ & 55 \\
$\delta-\mathrm{CuTi}$ & $\mathrm{P} 4 / \mathrm{mmm}$ & 2 & $49.8 \pm 0.8$ & $46.3 \pm 0.9$ & $3.4 \pm 0.1$ & $0.5 \pm 0.1$ & 32 \\
$\gamma-\mathrm{CuTi}$ & $\mathrm{P} 4 / \mathrm{nmm}$ & 3 & $48.8 \pm 0.3$ & $47.7 \pm 0.4$ & $3.1 \pm 0.2$ & $0.4 \pm 0.1$ & 8 \\
$\mathrm{CuTi}_{3}(\mathrm{Ni})$ & $\mathrm{P} 4 / \mathrm{mmm}$ & 4 & $68.8 \pm 1.3$ & $23.7 \pm 1.5$ & $6.2 \pm 0.1$ & $1.3 \pm 0.1$ & 5 \\
\hline
\end{tabular}

The phase evolution of powders occurred in the course of ball-milling was investigated. A preliminary experiment was performed with 60/1 balls to powder ratio (BPR). After $15 \mathrm{~h}$ of milling the structure was examined by XRD. As can be seen in Table 2, the structure has not become fully amorphous; two phases remained in the powder, $\mathrm{CuTi}_{3}(\mathrm{Ni})$ and $\mathrm{Ti}_{2} \mathrm{CuNi}$ of 17.00 $30.00 \mathrm{~nm}$ and $15.00-20.00 \mathrm{~nm}$, respectively.

Table 2: Features of crystallite based on the XRD of amorphous structure in the case of $\mathrm{Ti}_{48} \mathrm{Cu}_{39.5} \mathrm{Ni}_{10} \mathrm{Co}_{2.5}$ alloy

\begin{tabular}{|c|c|c|c|c|c|c|c|c|}
\hline \multirow{3}{*}{$\begin{array}{l}\text { milling } \\
\text { time, } \mathrm{h}\end{array}$} & \multirow{3}{*}{$\begin{array}{c}\text { ball/ } \\
\text { powder } \\
\text { ratio }\end{array}$} & \multirow{3}{*}{$\begin{array}{c}\text { amorphous } \\
\text { fraction, } \\
\mathrm{m} / \mathrm{m} \%\end{array}$} & \multicolumn{4}{|c|}{ amorphous halo } & \multirow{3}{*}{$\begin{array}{c}\text { crystallite } \\
\text { size of } \\
\mathrm{CuTi}_{3}(\mathrm{Ni}), \\
\mathrm{nm}\end{array}$} & \multirow{3}{*}{$\begin{array}{c}\text { crystallite } \\
\text { size of } \\
\mathrm{Ti}_{2} \mathrm{CuNi}, \\
\mathrm{nm}\end{array}$} \\
\hline & & & \multicolumn{2}{|c|}{ first peak } & \multicolumn{2}{|c|}{ second peak } & & \\
\hline & & & $\begin{array}{c}\text { position, } \\
\mathrm{nm}\end{array}$ & $\begin{array}{c}\text { size, } \\
\mathrm{nm}\end{array}$ & $\begin{array}{c}\text { position, } \\
\mathrm{nm}\end{array}$ & $\begin{array}{r}\text { size, } \\
\mathrm{nm}\end{array}$ & & \\
\hline 5 & \multirow{4}{*}{$80 / 1$} & 97 & 0.2152 & 0.19 & 0.1258 & 0.25 & $0.18-0.29$ & - \\
\hline 10 & & 91 & 0.2152 & 0.18 & 0.1263 & 0.19 & $0.18-0.29$ & - \\
\hline 15 & & 88 & 0.2148 & 0.18 & 0.1274 & 0.12 & $0.17-0.30$ & - \\
\hline 20 & & 90 & 0.2145 & 0.16 & 0.1274 & 0.14 & $0.16-0.29$ & - \\
\hline 15 & $60 / 1$ & 87 & 0.2212 & 0.15 & 0.1341 & 0.08 & $\begin{array}{c}17.00- \\
30.00\end{array}$ & $\begin{array}{l}15.00- \\
20.00\end{array}$ \\
\hline
\end{tabular}

The ratio of the weight of the balls to powder (BPR) has a significant effect on the milling process [10]. At a high BPR the number of collisions per unit time increases and powder can get more energy for structure transformation. Therefore, the milling was performed at a higher BPR equal to 80/1. The phase evolution of powder caused by high energy ball-milling was plotted as function of milling time, which can be seen in Fig. 1 c, d. Drastic change has occurred in the structure owing to $5 \mathrm{~h}$ of milling. Three phases of four have disappeared; their crystalline structures have transformed to an "X-ray amorphous structure" (hereinafter referred to as amorphous structure). Two broad diffuse halos remained indicating amorphization progress. The peak phases applied for amorphous determination as well as the Rietveld refinement of nanocrystalline phases are displayed in Fig. 2 as a characteristic example. The presence of 1-2 $\mathrm{nm}$ sized crystallites is observed, which is intermediate in size between the initial phases and the short-range order domains in amorphous structure. This observation is confirmed by the presence of two broad peaks similar in position to the peaks of the initial phases. The position of peak is referred to a range order with $d_{1}$ as dominant interatomic distance in the short-range order domain, and largest short range order domain size can be 


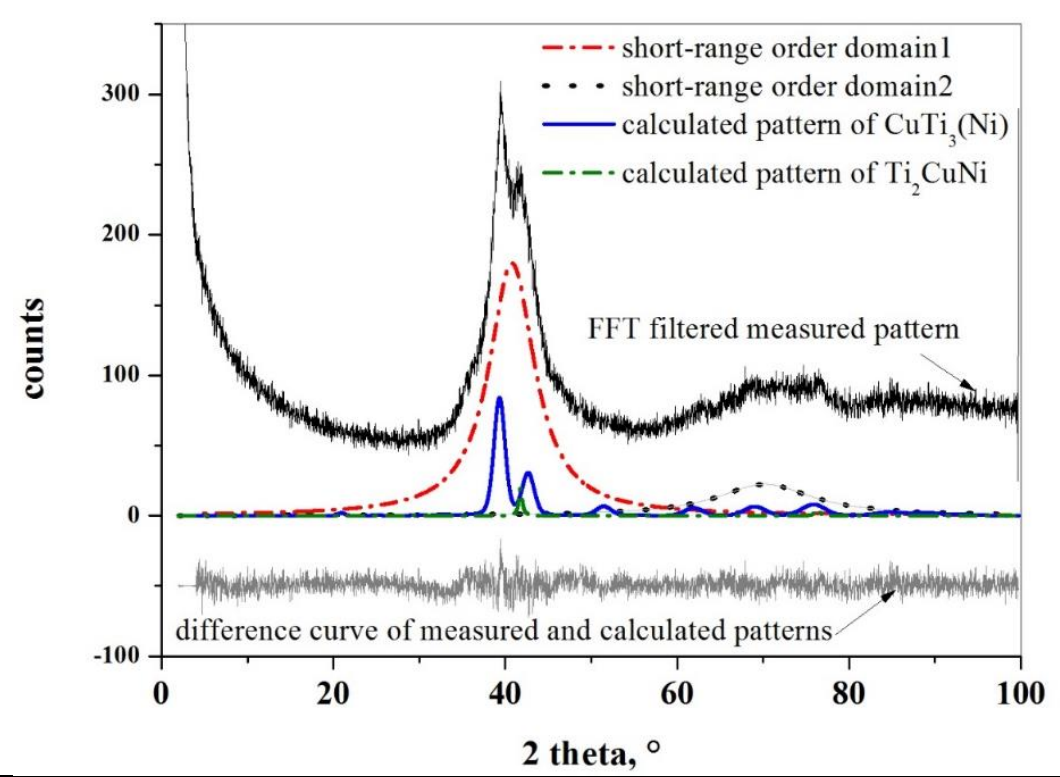

Fig. 2: Calculated peak phases and amorphous halo of $\mathrm{Ti}_{48} \mathrm{Cu}_{39.5} \mathrm{Ni}_{10} \mathrm{Co}_{2.5}$ alloy after $15 \mathrm{~h}$ of milling in the case of $60 / 1$ ball/powder ratio

approximated from the peak width (Fig. $1 \mathrm{~d}$ ). The amorphous fraction decreases up to $15 \mathrm{~h}$ of milling time. The position of the first peak shifts towards lower values; however, the second peak position shifts towards higher values (Table 2). The size of short-range order domains belonging to both peaks decreases continuously, i.e. the local ordering decreases. Only the $\mathrm{CuTi}_{3}(\mathrm{Ni})$ phase can be detected by XRD during the whole milling process ranging from 5 to $20 \mathrm{~h}$ (Fig. 1). This indicates high stability of the $\mathrm{CuTi}_{3}(\mathrm{Ni})$ phase against milling. It should also be noted that the fraction of nanocrystalline $\mathrm{CuTi}_{3}(\mathrm{Ni})$ phase increases due to milling up to 15 $\mathrm{h}, \mathrm{CuTi}_{3}(\mathrm{Ni})$ phase crystallizes from amorphous structure induced by mechanical milling. Due to further milling the fraction of nanocrystalline $\mathrm{CuTi}_{3}(\mathrm{Ni})$ decreases, which means that the amorphous structure forms from the crystallized $\mathrm{CuTi}_{3}(\mathrm{Ni})$. In the case of $\mathrm{CuTi}_{3}(\mathrm{Ni})$, the amorphous-nanocrystalline transition is a reversible process as can be seen from XRD results. The size of $\mathrm{CuTi}_{3}(\mathrm{Ni})$ nanocrystalline phase approaches the size of short-range order domains in amorphous structure (Table 2). fraction is almost the same. However, the $\mathrm{Ti}_{2} \mathrm{CuNi}$ phase is not detected by $\mathrm{XRD}$ and the size of the $\mathrm{CuTi}_{3}(\mathrm{Ni})$ phase reduces very significantly (Table 2). 

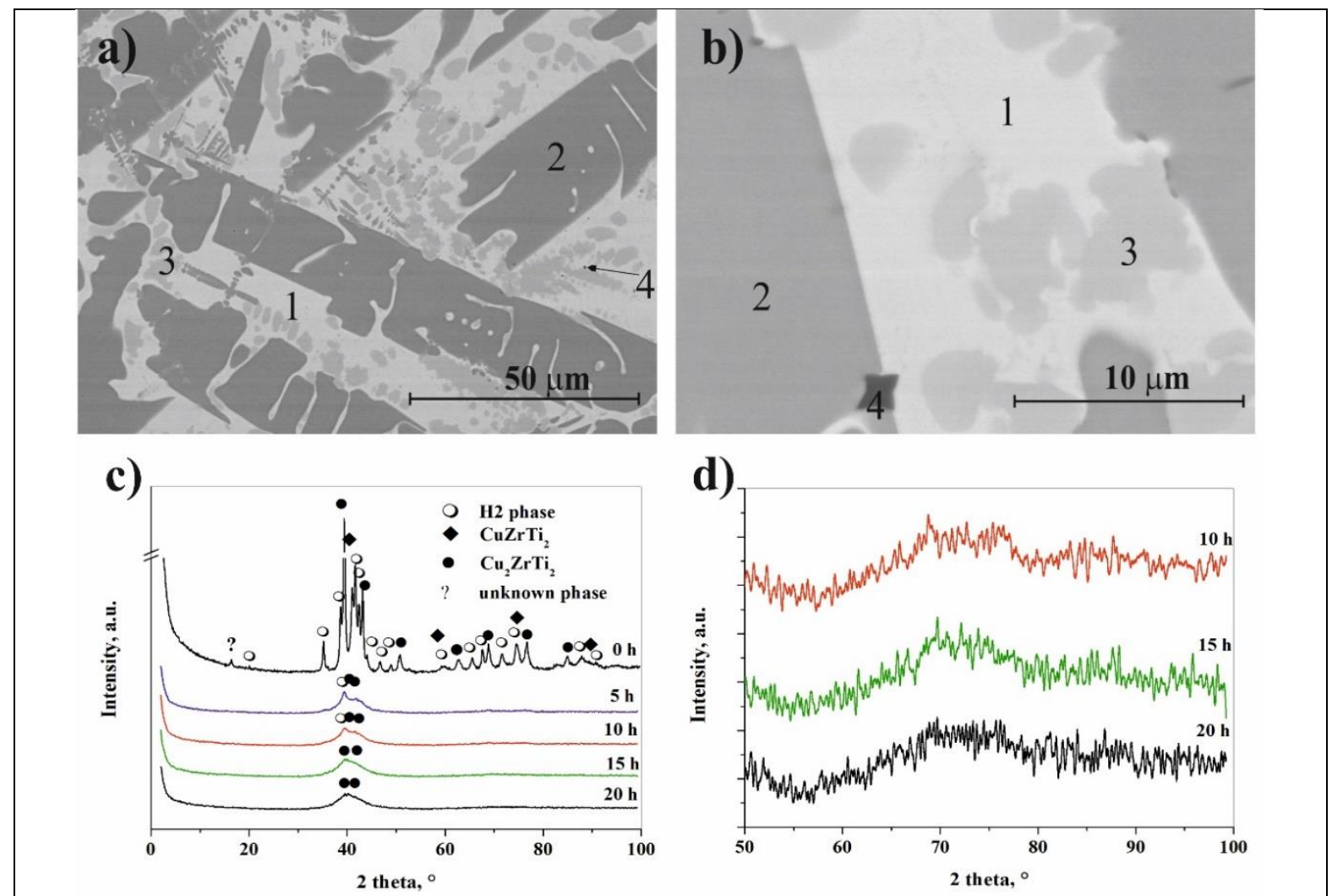

Fig. 3: Backscattered SEM (BSEM) images $(a, b)$ and XRD patterns of powder with different milling time (c, d) of $\mathrm{Ti}_{48} \mathrm{Cu}_{39.5} \mathrm{Zr}_{10} \mathrm{Co}_{2.5}$ alloy.

Replacing Ni by $\mathrm{Zr}$, five phases can be observed in the master alloy (Fig. 3). However, comparing the microstructures of the two alloys significant difference can be observed based on the SEM images (Fig. 3 a, b). According to XRD, a hexagonal phase (hereafter denoted as $\mathrm{H} 2$ ) is the matrix, which is a Cu-Ti-rich phase (Table 3) reported in [18] (Fig. 3 a, b denoted as 1). The lattice parameters are $a=0.5105 \mathrm{~nm}$ and $c=0.8231 \mathrm{~nm}$. Considerable amounts of the $\mathrm{Cu}_{2} \mathrm{ZrTi}_{2}$ phase with dendritic morphology can be seen in the matrix (Fig. 3a, b denoted as 2). The composition is different from the equilibrium composition; the $\mathrm{Cu}$ content is less (Table 3). Another dendritic Ti-Cu-based phase solidified in the matrix (Fig. 3). However, this phase cannot be identified by XRD because this phase is probably isomorphic with $\mathrm{Cu}_{2} \mathrm{ZrTi}_{2}$ phase and their peaks are overlapped. Using EDX, the composition of this phase was found to be $\mathrm{Ti}_{59.5 \pm 1.3} \mathrm{Cu}_{26.6 \pm 1.3} \mathrm{Zr}_{8.3 \pm 0.1} \mathrm{Co} .6 \pm 0.1$. Minor amounts of cubic $\mathrm{CuZrTi}_{2}$ phase can be found in the sample (denoted as 3). Very few grains with the Ti-content above 80 at. $\%$ can also be observed (denoted as 5). Their concentration is less than $1 \mathrm{~m} / \mathrm{m} \%$, which is below the detection limit of XRD. One of the peaks is unknown at $0.5402 \mathrm{~nm}$ (Fig. 3). All the phases dissolve $\mathrm{Zr}$ and Co as well (Table 3). The volume fractions of the different phases are summarized in Table 3. Further milling process has not been implemented because according to EDX attached to the scanning electron microscope, traces of $\mathrm{Fe}, \mathrm{Ni}$ impurities are present in the powder after $20 \mathrm{~h}$ milling time. The average Brinell hardness of the master alloy is $353 \pm 12 \mathrm{HB} 1 / 30$, i.e. the $\mathrm{Ti}_{48} \mathrm{Cu}_{39.5} \mathrm{Zr}_{10} \mathrm{Co}_{2.5}$ master alloy is one and a half times as hard as the $\mathrm{Ti}_{48} \mathrm{Cu}_{39.5} \mathrm{Ni}_{10} \mathrm{Co}_{2.5}$ alloy.

Table 3: Chemical composition and volume fraction of different phases in arc-melted 


\begin{tabular}{|c|c|c|c|c|c|c|c|}
\hline Phase & space group & Area & Ti, at. \% & $\mathrm{Cu}$, at. \% & Zr, at. \% & Co, at. \% & $\begin{array}{c}\text { fraction in } \\
\text { crystalline } \\
\text { volume, \% }\end{array}$ \\
\hline $\mathrm{H} 2$ & $\mathrm{P} 63 / \mathrm{mmc}$ & 1 & $34.9 \pm 1.1$ & $46.1 \pm 1.0$ & $17.4 \pm 0.4$ & $1.6 \pm 0.2$ & 42 \\
\hline $\mathrm{Cu}_{2} \mathrm{ZrTi}_{2}$, & $\mathrm{P} 4 / \mathrm{mmm}$ & 2 & $69.0 \pm 0.2$ & $26.1 \pm 0.4$ & $3.5 \pm 0.2$ & $1.4 \pm 0.2$ & \multirow{2}{*}{43} \\
\hline $\begin{array}{c}\mathrm{Ti}-\mathrm{Cu} \text { rich } \\
\text { dendrite }\end{array}$ & unknown & 3 & $59.5 \pm 1.3$ & $26.6 \pm 1.3$ & $8.3 \pm 0.1$ & $5.6 \pm 0.1$ & 14 \\
\hline $\begin{array}{c}\mathrm{CuZrTi} \\
\text { Ti-rich } \\
\text { phase }\end{array}$ & Pm-3m & 4 & $45.6 \pm 0.4$ & $38.1 \pm 0.2$ & $8.1 \pm 0.3$ & $8.2 \pm 0.4$ & $\leq 1$ \\
\hline
\end{tabular}

182

183

184

185

186

187

188

189

190

191

192

193

194

195

196

197

198

199

200

201

202

203

204

In the case of $\mathrm{Ti}_{48} \mathrm{Cu}_{39.5} \mathrm{Zr}_{10} \mathrm{Co}_{2.5}$ alloy, preliminary test was performed applying 60/1 BPR. The powder contained nanocrystals of two initial phases (Table 4 ) after $15 \mathrm{~h}$ of milling. The BPR was increased to 80/1. The amorphization process of structure is not so rapid than in the $\mathrm{Ni}$ containing alloy system. After $5 \mathrm{~h}$ of milling the amorphous structure is still undetectable (Fig. 3). Nanocrystalline form of $\mathrm{H} 2$ and $\mathrm{Cu}_{2} \mathrm{ZrTi}_{2}$ phases can be detected by XRD (Table 4). The amorphous structure appeared owing to $10 \mathrm{~h}$ of milling. A great change has occurred in the crystalline to amorphous ratio due to $15 \mathrm{~h}$ of milling. The $\mathrm{H} 2$ phase has disappeared and only $\mathrm{Cu}_{2} \mathrm{ZrTi}_{2}$ phase remained with crystallite size of $1.5-2.6 \mathrm{~nm}$ up to $20 \mathrm{~h}$ of milling. However, the amorphous fraction cannot reach approximately the same amount than in the case of $\mathrm{Ni}$ contain alloy. The amorphization reaction was not completed. This indicates that the kinetic energy of the milling process is insufficient for destabilization of the $\mathrm{Cu}_{2} \mathrm{ZrTi}_{2}$ crystalline phase to occur amorphization by the accumulation of structural defects such as vacancies, dislocations, grain boundaries, and anti-phase boundaries. Concerning the BPR it can be established, that increasing the BPR the amorphous fraction significantly increases; the $\mathrm{H} 2$ phase disappears but the $\mathrm{Cu}_{2} \mathrm{ZrTi}_{2}$ phase remains.

Table 4: Features of crystallite based on the XRD of amorphous structure in the case of $\mathrm{Ti}_{48} \mathrm{Cu}_{39.5} \mathrm{Zr}_{10} \mathrm{Co}_{2.5}$ alloy

\begin{tabular}{|c|c|c|c|c|c|c|c|c|}
\hline \multirow{3}{*}{$\begin{array}{l}\text { milling } \\
\text { time, } \mathrm{h}\end{array}$} & \multirow{3}{*}{$\begin{array}{l}\text { ball/ } \\
\text { powder } \\
\text { ratio }\end{array}$} & \multirow{3}{*}{$\begin{array}{c}\text { amorphous } \\
\text { fraction, } \\
\mathrm{m} / \mathrm{m} \%\end{array}$} & \multicolumn{4}{|c|}{ amorphous halo } & \multirow{3}{*}{$\begin{array}{c}\text { crystallite } \\
\text { size of the } \\
\text { H2 phase, } \\
\text { nm }\end{array}$} & \multirow{3}{*}{$\begin{array}{c}\text { crystallite } \\
\text { size of the } \\
\mathrm{Cu}_{2} \mathrm{ZrTi}_{2} \\
\text { phase, } \\
\text { nm }\end{array}$} \\
\hline & & & \multicolumn{2}{|c|}{ first peak } & \multicolumn{2}{|c|}{ second peak } & & \\
\hline & & & $\begin{array}{c}\text { position, } \\
\text { nm }\end{array}$ & $\begin{array}{c}\text { size, } \\
\mathrm{nm}\end{array}$ & $\begin{array}{c}\text { position, } \\
\mathrm{nm}\end{array}$ & $\begin{array}{c}\text { size, } \\
\text { nm }\end{array}$ & & \\
\hline 5 & \multirow{4}{*}{$80 / 1$} & - & - & - & - & - & $0.27-0.42$ & $0.20-0.36$ \\
\hline 10 & & 13 & 0.2241 & 0.11 & 0.1344 & 0.06 & $0.24-0.38$ & $0.17-0.29$ \\
\hline 15 & & 63 & 0.2174 & 0.15 & 0.1334 & 0.08 & - & $0.15-0.26$ \\
\hline 20 & & 69 & 0.2181 & 0.14 & 0.1330 & 0.06 & - & $0.15-0.26$ \\
\hline 15 & $60 / 1$ & 40 & 0.2142 & 0.15 & 0.1229 & 0.06 & $0.28-0.44$ & $0.15-0.26$ \\
\hline
\end{tabular}

Fig. 4 shows the cross sections of particles after different milling time using 80/1 BPR. The remaining phases are clearly seen in the particles after $10 \mathrm{~h}$ of milling (Fig. 4a, b). The microhardness of $\mathrm{Ti}_{48} \mathrm{Cu}_{39.5} \mathrm{Ni}_{10} \mathrm{Co}_{2.5}$ and $\mathrm{Ti}_{48} \mathrm{Cu}_{39.5} \mathrm{Zr}_{10} \mathrm{Co}_{2.5}$ particles is $\mathrm{HV}_{0.01} 519 \pm 40$ and $630 \pm 55$, respectively. No phase is observed in the powder after $20 \mathrm{~h}$ of milling. 

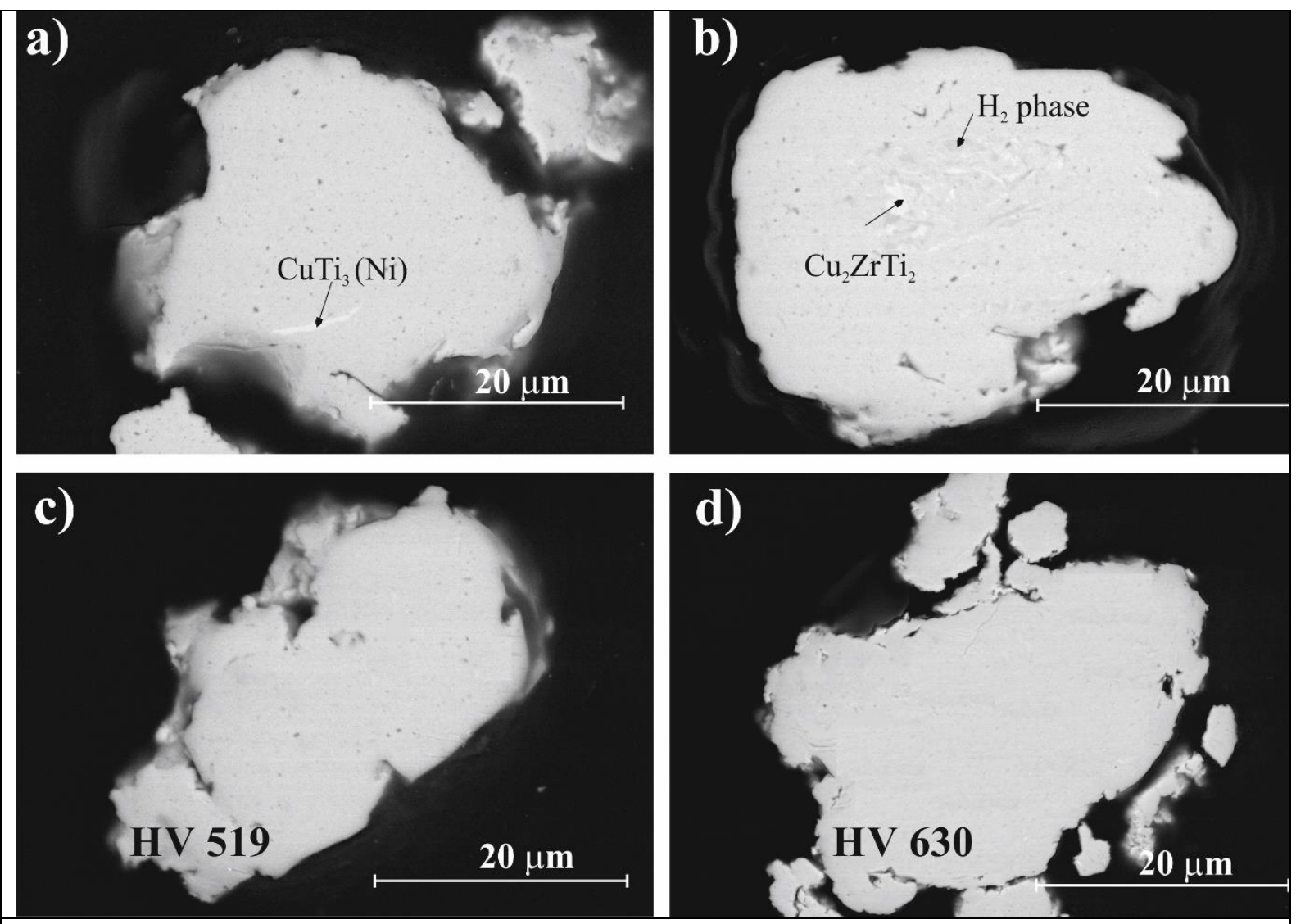

Fig. 4: Microstructure evolution of $\mathrm{Ti}_{48} \mathrm{Cu}_{39.5} \mathrm{Ni}_{10} \mathrm{Co}_{2.5}$ (a, c) and $\mathrm{Ti}_{48} \mathrm{Cu}_{39.5} \mathrm{Zr}_{10} \mathrm{Co}_{2.5}$ (b, d) alloys with different milling time: $10 \mathrm{~h}(\mathrm{a}, \mathrm{b})$ and $20 \mathrm{~h}(\mathrm{c}, \mathrm{d})$

In Fig. 5 the results of the particle size distribution measurement can be seen, where the volume ratio is plotted as function of the particle size in the case of different milling times. In Fig. b3 the results after 5, 10, 15, and 20 hours are presented and in B4 (hol található az utóbbi 2 ábra?) the results after 10, 15 and 20 hours of milling. The particle size in all cases is in the range 7 to $300 \mu \mathrm{m}$. It can be seen that the particle size continuously decreases as function of the milling time in the case of the $\mathrm{Ti}_{48} \mathrm{Cu}_{39.5} \mathrm{Ni}_{10} \mathrm{Co}_{2.5}$ alloy. The median particle size decreases in this case from $85 \mu \mathrm{m}$ ( $5 \mathrm{~h}$ of milling) to $33.73 \mu \mathrm{m}$ ( $20 \mathrm{~h}$ of milling). On the contrary, in the case of the $\mathrm{Ti}_{48} \mathrm{Cu}_{39.5} \mathrm{Zr}_{10} \mathrm{Co}_{2.5}$ alloy, the particle size does not decrease significantly during milling, the median particle size decreases only from $70.7 \mu \mathrm{m}$ (10 h of milling) to $54.36 \mu \mathrm{m}(20 \mathrm{~h}$ of milling). The mode size shows the same changes, in the $\mathrm{Ti}_{48} \mathrm{Cu}_{39.5} \mathrm{Ni}_{10} \mathrm{Co}_{2.5}$ alloy it decreases from $82.68 \mu \mathrm{m}$ to $31.96 \mu \mathrm{m}$, while in the $\mathrm{Ti}_{48} \mathrm{Cu}_{39.5} \mathrm{Zr}_{10} \mathrm{Co}_{2.5}$ alloy from $72.11 \mu \mathrm{m}$ to $54.97 \mu \mathrm{m}$. Analysis of correlation between the particle size and microhardness shows that the $\mathrm{Zr}$ containing particles fractured to a smaller extent than the Ni containing particles because the $\mathrm{Zr}$ containing particles have higher strength. 

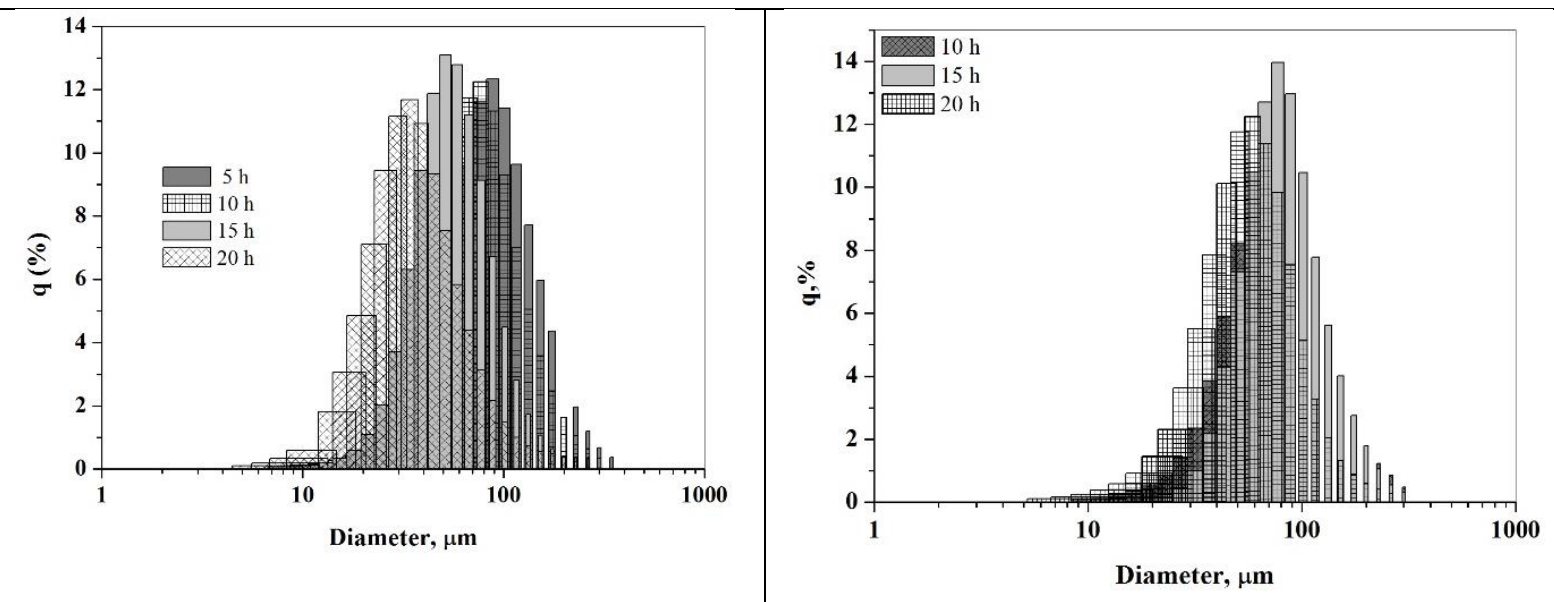

Fig. 5: Effect of the milling time on the particle size in the case of $\mathrm{Ti}_{48} \mathrm{Cu}_{39.5} \mathrm{Ni}_{10} \mathrm{Co}_{2.5}$ (a) and $\mathrm{Ti}_{48} \mathrm{Cu}_{39.5} \mathrm{Zr}_{10} \mathrm{Co}_{2.5}$ alloy

We examined the details of thermal stability of both milled powders. As a result, no glass transition can be observed for these alloys (Fig. 6). In the case of the $\mathrm{Ti}_{48} \mathrm{Cu}_{39.5} \mathrm{Ni}_{10} \mathrm{Co}_{2.5}$ alloy, using 60/1 BPR two exothermic peaks can be seen up to $600^{\circ} \mathrm{C}$ after $15 \mathrm{~h}$ of milling. The onset temperature of crystallization is $394^{\circ} \mathrm{C}$. The two peaks of crystallization are overlapped. Increasing the BPR, the first exothermic peak presence is barely noticeable but the second peak is stronger (Fig. 6a) and is shifted to a higher temperature. The two DSC signals are different. However, it is understandable because the two microstructures are different: using 60/1 BPR $\mathrm{CuTi}_{3}(\mathrm{Ni})+\mathrm{Ti}_{2} \mathrm{CuNi}$ nanocrystalline phases are beside the amorphous structure, while using 80/1 BPR only $\mathrm{CuTi}_{3}(\mathrm{Ni})$ smallest nanocrystalline phases are beside the amorphous structure. In the case of $\mathrm{Ti}_{48} \mathrm{Cu}_{39.5} \mathrm{Zr}_{10} \mathrm{Co}_{2.5}$ alloy, using 60/1 BPR two flat exothermic peaks can be seen up to $600^{\circ} \mathrm{C}$ after $15 \mathrm{~h}$ of milling. Increasing the BPR, the both exothermic peaks become more pronounced but the peak temperatures are the same. The onset temperature of crystallization is $418.1^{\circ} \mathrm{C}$.
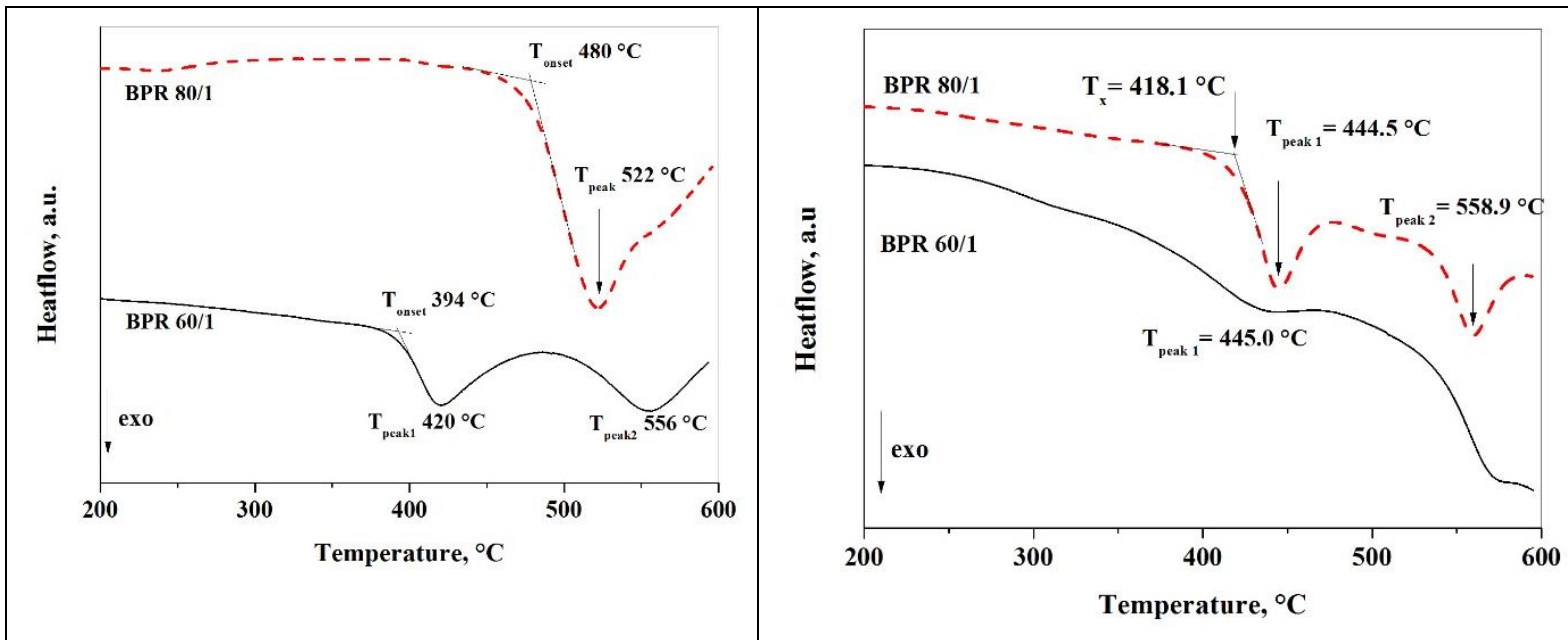

Fig. 6: DSC traces of the samples with $15 \mathrm{~h}$ milling time at a heating rate of $40^{\circ} \mathrm{C} / \mathrm{min}$ for the $\mathrm{Ti}_{48} \mathrm{Cu}_{39.5} \mathrm{Ni}_{10} \mathrm{Co}_{2.5}$ (a) and $\mathrm{Ti}_{48} \mathrm{Cu}_{39.5} \mathrm{Zr}_{10} \mathrm{Co}_{2.5}$ (b) alloy

\section{Conclusions}


High-energy ball-milling method has been successfully used to produce the Ti-based amorphous-nanocrystalline composite powders with nominal compositions of $\mathrm{Ti}_{48} \mathrm{Cu}_{39.5} \mathrm{Ni}_{10} \mathrm{Co}_{2.5}$ and $\mathrm{Ti}_{48} \mathrm{Cu}_{39.5} \mathrm{Zr}_{10} \mathrm{Co}_{2.5}$ (at. \%). $\mathrm{Ni}$ and $\mathrm{Zr}$ containing crystalline master alloys were ball-milled for 20 hours in total. All phases of both compositions dissolve Co.

The X-ray analysis revealed that the transformation of Ni containing crystalline powder to amorphous nanostructure can be achieved during ball-milling with high BPR after 5 hours of milling. Nanocrystalline phase of $\mathrm{CuTi}_{3}(\mathrm{Ni})$ of a grain size of $0.18-0.29 \mathrm{~nm}$ formed in the early stages of the milling process and remained stable until the end of milling. The amorphousnanocrystalline transition of this phase is a reversible process. The particle size of this alloy continuously decreases as function of the milling time.

The amorphization process of $\mathrm{Ti}_{48} \mathrm{Cu}_{39.5} \mathrm{Zr}_{10} \mathrm{Co}_{2.5}$ was not so rapid than that in the $\mathrm{Ni}$ containing alloy system. This confirms that kinetic energy of the milling process is insufficient for destabilization of the $\mathrm{Cu}_{2} \mathrm{ZrTi}_{2}$ nanocrystalline $(0.15-0.26 \mathrm{~nm})$ phase. The particle size does not decrease significantly during milling.

Microhardness of $\mathrm{Ti}_{48} \mathrm{Cu}_{39.5} \mathrm{Ni}_{10} \mathrm{Co}_{2.5}$ and $\mathrm{Ti}_{48} \mathrm{Cu}_{39.5} \mathrm{Zr}_{10} \mathrm{Co}_{2.5}$ particles after $20 \mathrm{~h}$ of milling was found to be $\mathrm{HV}_{0.01} 519 \pm 40$ and $630 \pm 55$, respectively.

\section{Acknowledgements}

The research work was carried out as part of the OTKA K 112623 project and GINOP-2.3.215-2016-00027 project.

\section{References}

[1] W. Klement, R. H. Willens, P. Duwez, Non-Crystalline Structure in Solidified Gold-Silicon Alloys, Nature. 187 (1960) 869.

[2] M.R. Debnath, H.J. Chang, E. Fleury, Effect of group 5 elements on the formation and corrosion behavior of Ti-based BMG matrix composites reinforced by icosahedral quasicrystalline phase, J.Alloy.Compd. 612 (2014) 134-142.

[3] Y.J. Huang, J. Shen, J.F. Sun, X.B. Yu, A new Ti-Zr-Hf-Cu-Ni-Si-Sn bulk amorphous alloy with high glass-forming ability, J.Alloy.Compd. 427 (2007) 171-175.

[4] A.A. Tsarkov, A.Yu. Churyumov, V.Yu. Zadorozhnyy, D.V. Louzguine-Luzgin, Highstrength and ductile (TieNi)-(CueZr) crystalline/amorphous composite materials with superelasticity and TRIP effect, J.Alloy.Compd. 658 (2016) 402-407.

[5] P. Gong, X. Wang, Y. Shao, N. Chen, X. Liu, K.F. Yao: A Ti-Zr-Be-Fe-Cu bulk metallic glass with superior glass-forming ability and high specific strength, Intermetallics. 43 (2013) 177-181.

[6] X.Z. Ma, D.Q. Ma, H. Xu, H.Y. Zhang, M.Z. Ma, X.Y. Zhang, R.P. Liu, Enhancing the compressive and tensile properties of Ti-based glassy matrix composites with $\mathrm{Nb}$ addition, J.Non-Cryst.Solids. 463 (2017) 56-63.

[7] A. Zhang, D. Chen, Z. Chen, Bulk Metallic Glass-Forming Region of Four Multicomponent Alloy Systems, Mater.T.JIM, 50 (2009) 1240-1242. 
[8] S. Yang, D. Li, X.S. Wang, J.W. Guo, S.F. Zhang, L. He, Mechanical behavior and wear performance of a Ti-based bulk metallic glass composite containing dendritic and intermetallic phases, Mater.Sci.Eng. A 672 (2016) 135-142.

[9] M.A. Turchanin, T.Ya. Velikanova, P.G. Agraval, A.R. Abdulov, L.A. Dreval, Thermodynamic Assessment of the Cu-Ti-Zr System. III. Cu-Ti-Zr System, Powder.Metall.Met. C+. 47, (2008) 9-10.

[10] C. Suryanarayana, Mechanical alloying and milling, Prog.Mat.Science. 46 (2001) 1-184.

[11] X.H. Lin and W.L. Johnson, Formation of Ti-Zr-Cu-Ni bulk metallic glasses, J.Appl.Phys. 78 (1995) 6514-6519.

[12] Zhang, D. Chen, Z. Chen, Bulk metallic Glass-Forming Region of Four Multicomponent Alloy Systems, Mater.T.Jim. 50 (2009) 1240-1242.

[13] D.V. Louzguine, A. Inoue, Formation of a nanoquasicrystalline phase in $\mathrm{Zr}-\mathrm{Cu}-\mathrm{Ti}-\mathrm{Ni}$ metallic glass, Appl.Phys.Lett. 78(13) (2001) 1841-1843.

[14] C.Pengjun, J.Dong, W. Haidong, F. Peigeng, Z. Anruo, Nanocrystallization of Cu-Based Bulk Glassy Alloys upon Annealing, Appl.Microsc. 46 (2016) 32-36.

[15] C. Triveno Rios, R. Contieri, Crystallization of amorphousCu49.7Ti31.8Zr11.3Ni7.2 alloy, Mat.Sci.Forum. 869 (2016) 464-469.

[16] D.V. Louzguine, A. Inoue, Crystallization behavior of Ti50Ni25Cu25 amorphous alloy, J.Mater.Science. 35 (2000) 4159-4164.

[17] P. Canale, C. Servant, Thermodynamic Assessment of the Cu-Ti System Taking into Account the New Stable Phase CuTi3, Z.Metallkd. 93(4) (2002) 273-76.

[18] Z. Jiang, H. Kato, T. Ohsuna, J. Saida, A. Inoue, K. Saksl, H. Franz, K. Stahl, Origin of nondetectable X-ray diffraction peaks in nanocomposite CuTiZr alloys, Appl.Phys.Lett. 83 (2003) 3299-3301. 